\title{
How oil palm cultivation is affecting mayfly assemblages in Amazon streams
}

\author{
Yulie Shimano $^{1 *}$ and Leandro Juen ${ }^{2}$ \\ ${ }^{1}$ Graduate Program in Zoology, Universidade Federal do Pará/Goeldi Museum, Rua Augusto Correia, n 1 Bairro Guamá, \\ 66.075-110, Belém, PA, Brazil \\ 2 Instituto de Ciências Biológicas, Universidade Federal do Pará, Rua Augusto Correia, n 1 Bairro Guamá, 66.075-110, Belém, PA, \\ Brazil
}

Received 01 July 2015; Accepted 19 January 2016

\begin{abstract}
The effects of the implantation of oil palm plantations on a series of environmental variables and the diversity and distribution of mayfly nymphs was investigated through a survey of 23 streams located in areas of plantation and natural forest in the eastern Amazon basin. Composition and richness of mayfly genera were compared among streams in order to verify which genera respond to the habitat disturbance gradient and determine thresholds for each variable. The genera number was higher in forest streams, although genus composition was similar between treatments. Only 9 of the 114 physical variables measured differed significantly between plantation and forest, and only three limnological variables were significantly different. Threshold Indicator Taxa ANalysis indicated that four genera were significantly associated with these variables. Of these, Miroculis and Ulmeritoides were associated with the largest number of variables. Given the different options available for use of soil in the Amazon basin, oil palm plantations appear to be one of the least deleterious for native fauna. In the Brazilian Amazon basin, government-sponsored zoning for the establishment of oil palm plantations as a strategy for the recuperation of degraded land thus appears to be a viable option for the reintegration of areas left damaged by agricultural activities, as long as the process is implemented adequately and monitored systematically. Also, legislation must be respected, in particular the permanent preservation of riparian zones, which may function as effective buffer zones to the runoff of pesticides and sediments.
\end{abstract}

Key words: Aquatic insects / Elaeis guineensis / TITAN / indicator species

\section{Introduction}

Over the past few decades, oil palm (Elaeis guineensis Jacq.) plantations have dramatically expanded throughout the tropics (Koh and Wilcove, 2008), driven primarily by high market prices and the excellent productivity of this species in comparison with other oil-producing crops (Butler and Laurance, 2009). An additional factor is the versatility of this palm, which can be used for the production of biofuels, cosmetics, foodstuffs, pharmaceutical products and other raw materials (Rocha and Castro, 2012). While the oil palm is a major source of economic growth as an alternative source of biofuel, the ongoing expansion of plantations contributes to deforestation, soil degradation, loss of diversity, wildfires and a range of social problems (Sheil et al., 2009).

\footnotetext{
*Corresponding author: shimano.yulie@gmail.com
}

Oil palm plantations are considered one of the main drivers of deforestation in the tropics (Kongsager and Reenberg, 2012). As they are less complex structurally than typical tropical forests, with trees of a uniform age, low canopy cover, sparse undergrowth, less stable microclimates, and are renewed every $25-30$ years, palm plantations are poor substitutes for native tropical forests (Fitzherbert et al., 2008). These characteristics are unfavorable to much of the wildlife that depends on forest habitats, and these plantations may eventually become a major threat to the preservation of tropical biodiversity (Butler and Laurance, 2009). In addition to the modification of habitats, groundwater quality may also be impacted by incorrect use of the land, given that intensive agricultural practices tend to contribute to an increase in erosion and siltation, as well as the leaching of nutrients and agricultural chemicals into the water table, streams and rivers (Foley et al., 2005). 
In 2008, Brazil was ranked 15th among the world's palm oil producing countries and corporate and political entities are encouraging the aggressive expansion of the industry (Butler and Laurance, 2009). Despite being one of the countries that most produces palm oil, Brazil is unable to meet domestic demand, which is another reason for believing that the total area planted will expand considerably over the next few years (Rocha and Castro, 2012).

On the other hand, the cultivation of the oil palm may represent a viable alternative for the reforestation of impacted areas in the Amazon basin (Ramalho-Filho and Mota, 2010). Oil palm cultivation may be an excellent alternative for the production of oils, and may thus provide an important resource for the Brazilian government's program that seeks to diversify and amplify the energy sources available to the country, as well as creating jobs and increasing the income of the populations involved in this activity (Ramalho-Filho and Mota, 2010). Given this perspective, the use of oil palm plantations as a strategy for the recuperation of deforested areas has received such strong incentives from the Brazilian government that over the past few years, a study has been developed to provide a database for the zoning of the anthropogenic habitats destined for the cultivation of Elaeis guineensis (http://www.cnps.embrapa.br/ zoneamento_dende/).

From an ecological viewpoint, few studies have evaluated the real effects of oil palm plantations on the planet's biodiversity, and no data whatsoever are available for the Amazon region. According to the data analyzed by Danielsen et al. (2008), mainly from Asia, the species richness of birds, lizards and mammals is invariably lower in areas with oil palm plantations, although the mean total richness of invertebrates may be unaffected and the diversity of some groups, such as ants, bees and moths, may actually increase in the plantation environment. However, Lucey et al. (2014) recorded a $22 \%$ reduction in the diversity of ants in palm plantations and Mercer et al. (2013) found that aquatic macroinvertebrates were more abundant and diverse in forested areas in comparison with oil palm plantations. A recent study carried out in Amazonia pointed out that the conversion of natural landscapes to oil palm plantation decreases environmental integrity and has led to a reduction in aquatic Heteroptera species richness (Cunha et al., 2015). Given the contradictory nature of the available evidence and the probable continuing expansion of plantations in the Brazilian Amazon basin, it has become increasingly important to understand the real effects of this monoculture on different groups of animals, in particular those most sensitive to environmental impacts, such as the aquatic macroinvertebrates.

A number of animal groups are used as bioindicators of environmental quality, and of those which may provide more systematic insights into the effects of oil palm plantations, the aquatic insects of the order Ephemeroptera (mayflies) may be among the most promising. The composition of a mayfly assembly may reflect impacts over a wide area (Shimano et al., 2013), considering that these insects spend most of their life in the waters of streams and lakes, the characteristics of which are influenced by the runoff of precipitation throughout the local drainage basin. A number of studies have recorded the response of mayfly (Ephemeroptera) species to different types of soil use, always identifying taxa associated with different land use types, such as cattle ranching (Bottová et al., 2012), the eutrophication of lentic habitats (Menetrey et al., 2008), pollutant concentrations (Eftenoiu et al., 2011), deforestation (Buss and Salles, 2007; Silva et al., 2010; Souza, et al., 2011) and urban areas (Hepp and Santos, 2009; Couceiro et al., 2012; Monteiro-Júnior et al., 2013).

On the basis of these findings, our aim was to verify how oil palm plantations affect environmental parameters and, in turn, the distribution of mayfly nymphs, and discover which genera respond to the gradient of disturbance caused by plantations. Two hypotheses were tested - (i) oil palm plantations cause changes in the natural structure of the environment and this will result in a significant difference in the composition and diversity of mayfly assemblages; and (ii) some taxa will be closely associated with one or other environmental extreme, given that, while some specialist species are highly sensitive to environmental impacts, other, more generalist species will be found in impacted areas. It is hoped that the evaluation of the effects of oil palm plantations on the diversity of mayfly assemblages at the genus level may provide valuable guidelines for the development of programs of water biomonitoring based on this group of insects. This biomonitoring would have a number of advantages, including the relatively straightforward procedures for the collection and identification of specimens, which would facilitate the participation of technicians or even laypersons.

\section{Materials and methods}

The present study focused on the Agropalma Agroindustrial complex in the municipality of Tailândia, located in the northeast of the Brazilian state of Pará. Agropalma is currently the largest producer of palm oil in Latin America, with a total of 39000 hectares (ha) of plantation (Agropalma, 2014). The company's natural forest reserves cover an area of approximately 50000 ha, divided into a number of fragments isolated within the area of the plantations (Fig. 1). These reserves are composed predominantly of typical Amazonian terra firme rainforest. The local climate is humid tropical, with a rainy season between December and May, and a less rainy season between June and November. Mean annual precipitation recorded between 1978 and 2008 was $2344 \mathrm{~mm}$, with the monthly means of up to $427 \mathrm{~mm}$ in March, and as low as $54 \mathrm{~mm}$ in September (Albuquerque et al., 2010). Mean annual temperature is approximately $26{ }^{\circ} \mathrm{C}$, and the relative humidity of the air around $85 \%$.

A total of 23 streams were sampled, 8 of which were located within forest reserves, in areas of primary forest, with the other 15 being located within oil palm plantations 


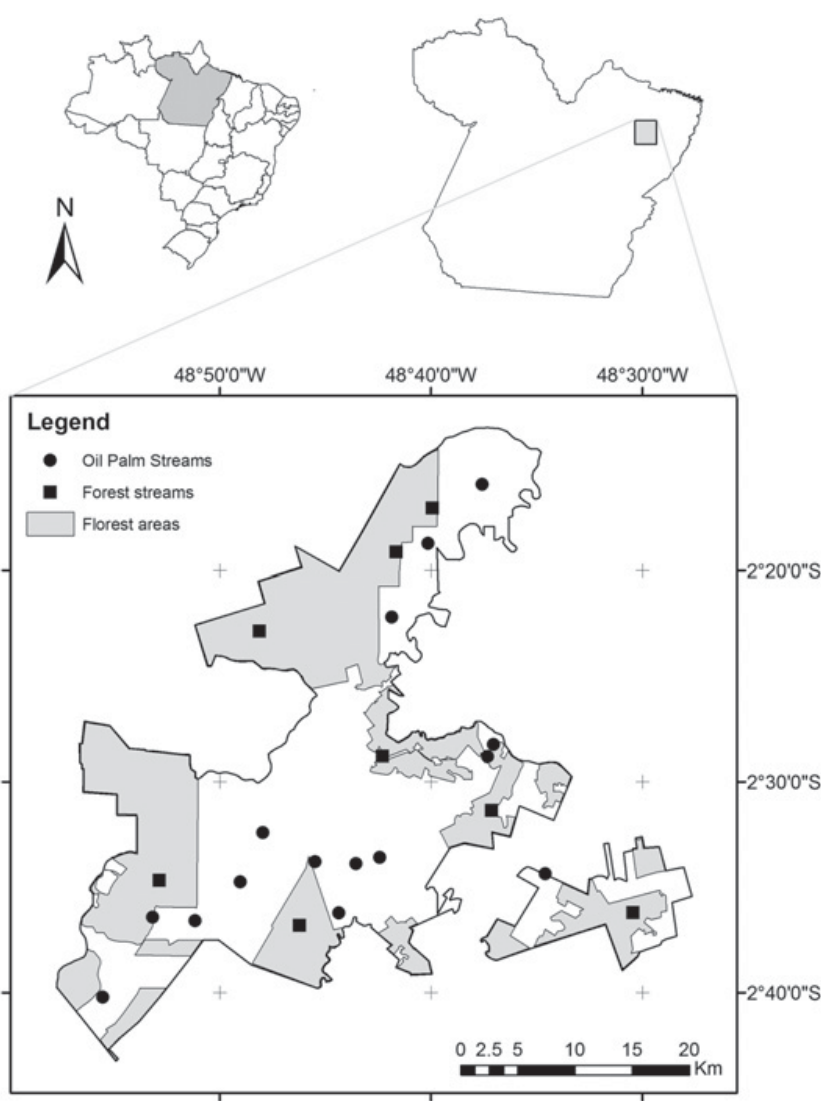

Fig. 1. Sampling sites of Ephemeroptera in oil palm plantation and forest areas, in the eastern Amazon basin, Tailândia, Pará (Brazil).

(Fig. 1). A $150 \mathrm{~m}$ stretch of each stream was demarcated as a standard sample plot, within which data were collected in the dry season periods of 2012 and 2013. Each sample plot was subdivided into 10 sectors of $15 \mathrm{~m}$ for the evaluation of habitat integrity, following the protocol described below.

For the collection of Ephemeroptera nymphs, the $15 \mathrm{~m}$ sectors were subdivided into three sectors of $5 \mathrm{~m}$, with specimens being collected only in the first two. This approach was adopted to increase the number of subsamples, necessary to estimate genus richness reliably. In each plot, then, 20 of the 30 subsectors were sampled.

In each segment, two samples of the substrate were collected using a dip netting $(18 \mathrm{~cm}$ in diameter, with a $0.05 \mathrm{~mm}$ mesh). The substrate selection criteria were based on the premise that organisms are associated with specific types of substrates. We therefore sampled the most different types to try and collect them all. In each segment, we observed the substrates present, and sought to consider samples with the greatest possible variability of substrates. This method of collection can be characterized as an active search type of procedure, in which the collector attempts to sample the greatest possible number of the substrates found along the length of a transect, with the objective of collecting the highest possible diversity of the target group, in this case, the Ephemeroptera. Furthermore, randomization is used in sampling with the purpose of minimizing the organism association effect in certain substrates. The material collected was sorted in the field and conserved in absolute ethanol. This procedure has been used successfully in previous field studies of Ephemeroptera (Shimano et al., 2010). The identification of the nymphs was based on the taxonomic key of Domínguez et al. (2006), and complementary works of reference. Voucher specimens were deposited in the zoological collection of the Federal University of Pará in Belém.

The physical conditions found at each stream were evaluated using a protocol adapted from Peck et al. (2006). This involved the measurement of a number of characteristics, including 26 variables of channel morphology, 29 concerning substrate type and quantity, 5 on streams hydraulics, 16 on the flow patterns of the channel, 4 on terrain (slope), 1 on sinuosity, 4 on riparian vegetation cover, 33 on the type and quantity of riparian vegetation cover, 60 different aspects of the types and size of the wood litter found in the stream bed and 32 on the possible types and quantity of refuges available for insects and their predators. Overall, then, a total of 210 measures of the physical environment were obtained for each stream. Nessimian et al.'s (2008) habitat integrity index (HII) was also applied to provide a general indicator of the integrity of the habitat at each stream.

In addition to these data, three measurements (at the extremes and the center of each $150 \mathrm{~m}$ plot) were taken of water temperature, turbidity, dissolved oxygen concentrations, conductivity, total dissolved solids, oxidation reduction potential (ORP) and $\mathrm{pH}$, to provide a mean parameter for each stream. Measurements were taken with a Horiba portable probe.

\section{Statistical analyses}

Genus richness was compared using the nonparametric Jackknife estimator (Coddington et al., 1991; Colwell and Coddington, 1994). This method estimates total richness by correcting observed richness (the number of taxa recorded) by a parameter calculated from the number of rare taxa (which were recorded in only one sample). This procedure provides a more reliable estimate of the richness of taxa in a community (Krebs, 1999), as well as a confidence interval, which permits the statistical analysis of the estimates collected at two or more sites, or at the same site during different periods. This analysis was run in EstimateS Win 7.5 software (Colwell, 2005).

A non-metric multidimensional scaling (NMDS) analysis was used to evaluate the effects of soil use on the composition of the Ephemeroptera assemblages, based on the presence and absence of genera at each stream, with the Jaccard index being used as a measure of dissimilarity (Legendre and Legendre, 2012). Differences between the groups ranked by the NMDS were tested using an analysis of similarity, or ANOSIM (Clarke and Warwick, 1994). These analyses (NMDS and ANOSIM) were run in the $\mathrm{R}$ program using the Vegan and MASS packages (R Development Core Team, 2014). 
Environmental variables were submitted to a preselection, where firstly, all metrics that presented zero value in more than $80 \%$ of the samples and a coefficient of variation less than $10 \%$ were excluded. In order to minimize the potential problem of multicolinearity in the environmental data, as well as to reduce the number of variables analyzed, correlation matrices were produced, and variables with a correlation of above 0.7 were excluded from the analysis, the ones with higher importance in the structuring of Ephemeroptera assemblages were selected according to the literature. Selected variables were evaluated by their ability to distinguish forest and oil palm plantation areas using the evaluation of the interquartiles bars overlap in box-whisker plots (Barbour et al., 1996). We consider sensitive variables that show no overlap of quartiles or present little overlap of quartiles, without overlap of medians. Subsequently, $t$ tests were applied to the remaining variables to select those that were different between the plantation and natural forest areas. The variables were log-transformed to limit the effect of variance heterogeneity.

A Threshold Indicator Taxa ANalysis - TITAN (Baker and King, 2010) was run for each variable that presented a significant difference between plantation and forest, for the identification of the genera that responded to the gradient of disturbance created by the oil palm plantations. This analysis aimed to detect changes in the distribution of the different taxa over a continuous environmental gradient and verify the existence and nature of specific associations in the frequency and relative abundance of the taxa along this gradient (Baker and King, 2010). This analysis was also based on the criteria of the Indicator species index (IndVal), i.e., specificity and fidelity (Dufrêne and Legendre, 1997) and the Change Point Analysis - nCPA (King and Richardson, 2003), which associates the taxa with continuous environmental scores and creates confidence limits and points of change (positive or negative) in the taxa, which define the limits of a community for each variable tested (Baker and King, 2010; King et al., 2011).

As the environmental parameters measured may either increase or decrease according to the presence of oil palm plantations, the results of the study will be presented separately in order to avoid possible problems of interpretation. The limnological and physical variables were also analyzed separately, given that they may reflect changes in the environment in different ways. Limnological variables are altered temporarily by climatic processes, such as rainfall, and tend to return rapidly to their normal conditions, whereas physical variables may take many years to return to their original state, depending on the degree of impact.

\section{Results}

\section{Oil palm plantations and the distribution of Ephemeroptera nymphs}

A total of 1232 specimens were collected during the present study, representing 21 genera. Comparing areas of

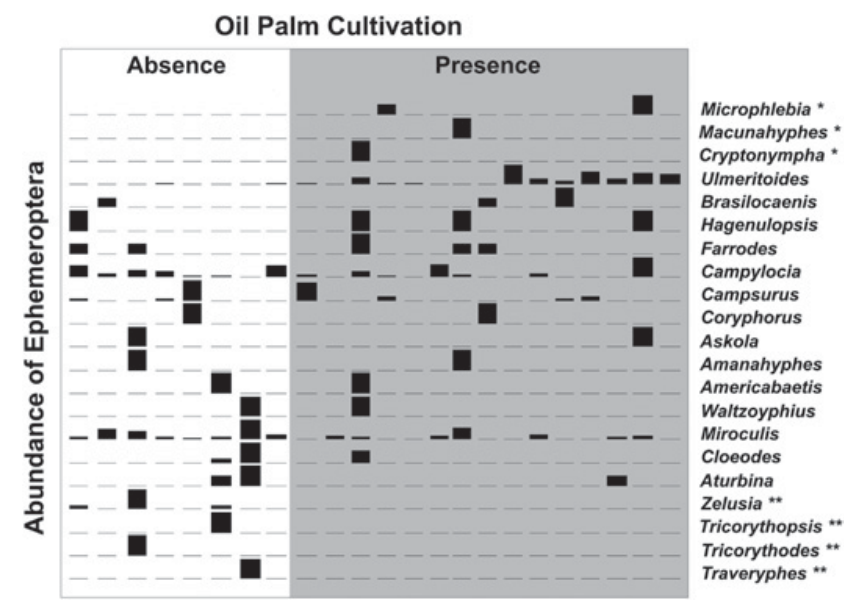

Fig. 2. Abundance of Ephemeroptera genera collected in Amazonian streams, ranked by the presence (gray background) and absence (white) of oil palm plantations. (*) genera found only in areas with oil palm plantations and $(* *)$ genera present only in forest areas.

forest and plantation, there was no difference in the mean abundance of Ephemeroptera $(t=-1.12$, d.f. $=21$ and $P=0.27)$. However, the estimates of total taxon richness in the two environments indicate that the forest streams contained $30 \pm 6.89$ (richness mean $\pm 95 \%$ confidence interval), around ten additional genera, on average, in comparison with the streams located within oil palm plantations $(20 \pm 5.04)$.

With regard to the taxonomic composition, three genera-Zelusia, Tricorythopsis and Tricorythodes - were unique to the forest streams (i.e., they were found only in these habitats), and three others - Microphlebia, Macunahyphes and Cryptonympha - were unique to plantation streams (Fig. 2). However, when the streams were ranked according to the presence/absence of genera, the forest and plantation sites were not well differentiated (Fig. 3), a pattern confirmed by the ANOSIM ( $R=0.049$ and $P=0.252$ ), reinforcing the conclusion that there was no significant difference in the composition of the mayfly assemblages in the two types of habitat.

\section{Oil palm plantations and environmental variables}

A total of 114 physical and 7 limnological variables were evaluated in relation to the differences between oil palm plantations and native forest. Of these, only nine physical and three limnological variables differed significantly between habitats (Fig. 4, Appendix Table A1).

The physical variables with significantly higher values in the plantation streams were live trees and roots. In the forest streams, by contrast, the percentages of algae, the mean proportion of bank undercut, the percentage of fine sediment, the HII, the mean slope of the bank, the width:depth ratio of the stream and the percentage of wood fragments were all higher (Fig. 4). In the case of the limnological variables, $\mathrm{pH}$ and temperature were higher in 


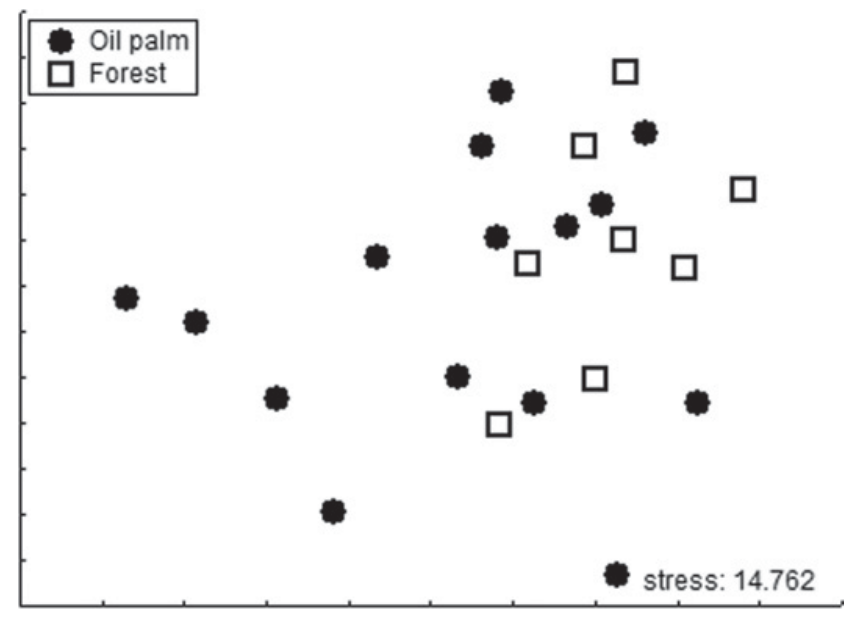

Fig. 3. Ordination (NMDS) of the sampling sites in oil palm plantation and forest areas, in the eastern Amazon basin, Tailândia, Pará, based on the presence or absence of the Ephemeroptera genera.

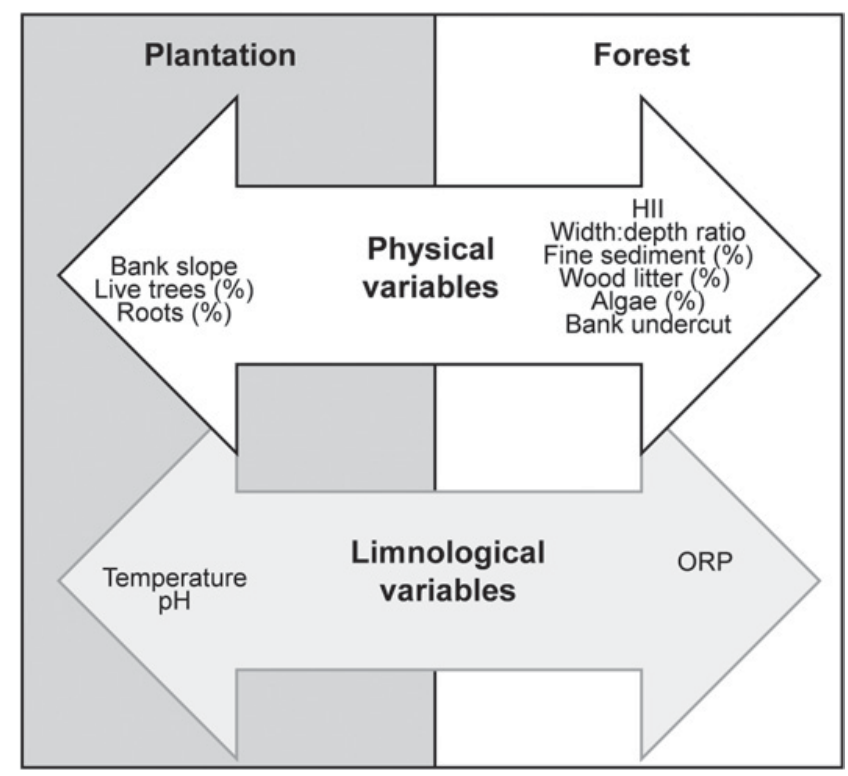

Fig. 4. Diagram showing the physical and limnological variables of the plantation and forest streams, and their association (positive or negative) with conservation levels.

the plantation streams, whereas the highest ORP values were recorded in the forest streams (Fig. 4).

\section{Environmental variables and Ephemeroptera nymphs}

Four Ephemeroptera genera presented an association with at least one variable (physical or limnological) that increased in either the plantation or forest streams. In the plantation streams (Table 1), Campylocia and Miroculis were negatively associated with $\mathrm{pH}$ and low temperatures (found in the forest streams [- ]), while Ulmeritoides was positively associated $(+)$ with these variables, indicating a preference for the higher values recorded in the plantation streams (Table 1). In the case of physical variables, Miroculis was associated with low quantities of bank slope and fine roots, reinforcing its associations with forest streams. However, Campylocia presented a positive association with these variables, indicating its preference for the streams with plantation, but contradicting the findings for the limnological variables. Ulmeritoides presented a positive association with live trees and fine roots, indicating its preference for the oil palm streams. Campsurus, such as Miroculis, presented a negative association with fine roots, indicating a preference for forest habitats.

The ORP was the only limnological variable that returned a tendency to increase in forest streams (Table 2). Campylocia and Miroculis were positively associated with this variable, indicating a preference for forest habitats, while Ulmeritoides was negatively related to this variable (Table 2). Campsurus and Ulmeritoides were negatively associated with almost all the physical variables analyzed, with the exception of the proportion of bank undercut, indicating a strong association with the low values recorded for these variables in the plantation. The opposite pattern was recorded for Miroculis, which was positively associated with these same variables. Campylocia was negatively associated with the width:depth ratio of the streams, but positively with the proportion of bank undercut.

A comparative overview of the results (limnological and physical variables) indicate that Miroculis and Ulmeritoides presented the same type of association for all the significant patterns, whereas the other genera varied in their response, being associated with the higher values recorded in the plantation for some variables, and with the higher values recorded in the forest for others. In the specific case of Campsurus, the genus was only associated with physical variables.

Given that Miroculis and Ulmeritoides appear to be the most important indicators, environmental thresholds are presented here only for these two genera (Table 3 ). Analyzing limnological variables first (highlighted in bold in the table), in the specific case of the oxidation-reduction potential, there is an exact point $-324.5 \mathrm{mV}$ - at which Ulmeritoides tends to disappear and Miroculis begins to colonize. Ulmeritoides also tends to disappear at low $\mathrm{pH}$ values, especially those lower than 4.82 , when the water becomes more acid, whereas Miroculis tends to appear when the $\mathrm{pH}$ exceeds 4.5. Ulmeritoides also tends to disappear when the temperature of the water exceeds $26.41{ }^{\circ} \mathrm{C}$, whereas Miroculis avoids temperatures below $24.75{ }^{\circ} \mathrm{C}$. In habitats with intermediate temperatures, both genera may be found.

With regard to the physical variables (Table 3), Ulmeritoides is only present when alga is absent, e.g., although Miroculis tolerates a $0.2 \%$ coverage, on average. In relation to the relative dimensions of the stream, Miroculis tends to occur in streams which have a width:depth ratio of around four, whereas Ulmeritoides generally disappears when this value is equal to two. Fine sediment also plays a role - Miroculis tends to appear at values of above $8 \%$, whereas Ulmeritoides disappears at 
Table 1. Ephemeroptera genera associated with the environmental variables that increase in streams located near oil palm plantations. $(+)$ and $(-)$ indicate whether genera abundance increases or decreases in streams with oil palm plantations.

\begin{tabular}{|c|c|c|c|c|}
\hline Environmental variables that increase in plantation & Campsurus & Campylocia & Miroculis & Ulmeritoides \\
\hline \multicolumn{5}{|l|}{ Limnological variables } \\
\hline $\mathrm{pH}$ & & - & - & + \\
\hline Temperature & & - & - & + \\
\hline \multicolumn{5}{|l|}{ Physical variables } \\
\hline Bank slope & & + & - & \\
\hline Live trees $(\%)$ & & & & + \\
\hline Fine roots $(\%)$ & - & + & - & + \\
\hline
\end{tabular}

Table 2. Ephemeroptera genera associated with environmental variables that increase in streams located near natural forest. $(+)$ and $(-)$ indicate whether genera abundance increases or decreases in forest streams.

\begin{tabular}{|c|c|c|c|c|}
\hline Environmental variables that increase in forest & Campsurus & Campylocia & Miroculis & Ulmeritoides \\
\hline \multicolumn{5}{|l|}{ Limnological variables } \\
\hline ORP & & + & + & - \\
\hline \multicolumn{5}{|l|}{ Physical variable } \\
\hline HII & & & + & - \\
\hline Width:depth ratio & - & - & + & - \\
\hline Fine sediment & - & & + & - \\
\hline Wood litter $(\%)$ & - & & + & - \\
\hline Algae $(\%)$ & - & & + & - \\
\hline Bank undercut & & + & & \\
\hline
\end{tabular}

Table 3. Results of TITAN showing the change points for Miroculis and Ulmeritoides (only those environmental variables for which significant values were recorded).

\begin{tabular}{|c|c|c|c|c|c|c|c|c|c|c|c|}
\hline$\overline{\text { Genus }}$ & Variable & Change Point & Freq. & IndVal & $\mathrm{Z}$ & $5 \%$ & $95 \%$ & Purity & Reability & Increase in & (associated with) \\
\hline \multirow[t]{10}{*}{ Miroculis } & Alga $(\%)$ & 0.02 & 194 & 79.83 & 9.06 & 0.02 & 0.02 & 1.00 & 1.00 & Forest & $\mathrm{Z}+$ (forest) \\
\hline & Width:depth ratio & 4.00 & 194 & 66.44 & 10.24 & 3.33 & 7.33 & 1.00 & 1.00 & Forest & $Z+$ (forest) \\
\hline & Fine sediment $(\%)$ & 8.00 & 194 & 66.56 & 9.30 & 1.65 & 9.33 & 1.00 & 1.00 & Forest & $Z+$ (forest) \\
\hline & HII & 0.66 & 194 & 67.94 & 7.23 & 0.66 & 0.78 & 1.00 & 1.00 & Forest & $Z+$ (forest) \\
\hline & ORP* & 324.50 & 194 & 53.35 & 7.39 & 283.33 & 325.33 & 1.00 & 1.00 & Forest & $\mathrm{Z}+$ (forest) \\
\hline & Wood $(\%)$ & 36.78 & 194 & 66.07 & 8.01 & 20.69 & 38.15 & 1.00 & 1.00 & Forest & $Z+$ (forest) \\
\hline & Slope & 15.00 & 194 & 80.26 & 8.46 & 5.68 & 16.82 & 1.00 & 1.00 & Oil palm & $Z-$ (forest) \\
\hline & Fine roots $(\%)$ & 0.00 & 194 & 74.72 & 8.48 & 0.00 & 0.01 & 1.00 & 1.00 & Oil palm & $Z-$ (forest) \\
\hline & $\mathrm{pH}^{*}$ & 4.51 & 194 & 81.69 & 8.45 & 4.48 & 4.79 & 1.00 & 1.00 & Oil palm & $\mathrm{Z}-$ (forest) \\
\hline & Temperature* & 24.75 & 194 & 82.11 & 9.27 & 24.18 & 25.19 & 0.98 & 0.98 & Oil palm & $Z-$ (forest) \\
\hline \multirow[t]{11}{*}{ Ulmeritoides } & Algae (\%) & 0.00 & 61 & 37.24 & 10.62 & 0.00 & 0.01 & 1.00 & 1.00 & Forest & $\mathrm{Z}-($ oil palm $)$ \\
\hline & Width:depth ratio & 2.00 & 61 & 25.35 & 8.96 & 0.00 & 2.67 & 1.00 & 1.00 & Forest & $\mathrm{Z}-($ oil palm) \\
\hline & Bank undercut & 2.73 & 61 & 27.32 & 9.55 & 1.82 & 3.18 & 1.00 & 1.00 & Forest & $\mathrm{Z}-$ (oil palm) \\
\hline & Fine sediment $(\%)$ & 3.00 & 61 & 33.22 & 14.01 & 2.67 & 3.33 & 1.00 & 1.00 & Forest & $\mathrm{Z}-($ oil palm) \\
\hline & HII & 0.67 & 61 & 48.20 & 13.96 & 0.61 & 0.73 & 1.00 & 1.00 & Forest & $\mathrm{Z}-($ oil palm) \\
\hline & ORP* & 324.50 & 61 & 38.19 & 14.23 & 313.63 & 332.00 & 1.00 & 1.00 & Forest & $\mathrm{Z}-($ oil palm $)$ \\
\hline & Wood litter $(\%)$ & 11.63 & 61 & 24.94 & 8.33 & 8.54 & 22.14 & 1.00 & 1.00 & Forest & $\mathrm{Z}-$ (oil palm) \\
\hline & Fine roots $(\%)$ & 0.01 & 61 & 26.87 & 7.86 & 0.01 & 0.02 & 1.00 & 1.00 & Oil palm & $\mathrm{Z}+$ (oil palm) \\
\hline & Live trees & 21.82 & 61 & 30.20 & 10.78 & 20.68 & 22.50 & 1.00 & 1.00 & Oil palm & $\mathrm{Z}+$ (oil palm) \\
\hline & $\mathrm{pH}^{*}$ & 4.82 & 61 & 32.72 & 13.35 & 4.79 & 4.85 & 1.00 & 1.00 & Oil palm & $\mathrm{Z}+$ (oil palm) \\
\hline & Temperature* & 26.41 & 61 & 37.48 & 11.91 & 25.69 & 26.45 & 1.00 & 1.00 & Oil palm & $\mathrm{Z}+$ (oil palm) \\
\hline
\end{tabular}

*Limnological variables. In 'indication': $\mathrm{Z}+$ indicates a positive relation of the genus to the variable and $\mathrm{Z}-$ indicates a negative relation. 5 and $95 \%$ representing bootstrap quantile intervals captured the true thresholds. Purity is the mean proportion of correct response direction $(z)$ or $z+$ ) assignments, reliability is the mean proportion of $P$-values 0.05 or 0.01 among 500 simulation iterations, and Freq. is the number of non-zero observations.

values of below $3 \%$. In the case of the HII, there is an exact value - 0.66 - below which Miroculis is substituted by Ulmeritoides.

In relation to the wood litter, Miroculis tends to appear in streams with values of over $36.78 \%$, whereas
Ulmeritoides appears in streams with values below $11.63 \%$. Miroculis is only found where there are no fine roots $(0 \%)$, while Ulmeritoides appeared in streams with at least $0.01 \%$. The slope of the bank also played a role Miroculis tends to disappear from streams with a slope of 
less than $15^{\circ}$. Finally, Ulmeritoides tends to disappear when less than $2.73 \%$ of the bank has undercut and more than $21.83 \%$ of the stream has live trees.

\section{Discussion}

Despite the growing controversies over the negative impacts of the production of biofuels on land use and biodiversity, the oil palm industry continues to grow, driven by the increasing demand for edible vegetable oils (Corley, 2009). While any impact on the environment may result in modifications of a local community, there must be trade-offs between satisfying immediate human needs and guaranteeing the capacity of the ecosystem to provide goods and services in the future (Foley et al., 2005).

According to the zoning of palm oil production proposed by the Brazilian government, oil palm plantations should only be expanded in areas of degraded land (Koh and Wilcove, 2008), which would represent a more subtle way to protect the soil. However, future demand for foodstuffs and shifts in public policy are unpredictable, and any such strategy may ultimately be undermined by the economic benefits resulting from increased production of this resource. In particular, the expansion of oil palm plantations may displace less profitable activities, such as cattle ranching and even subsistence agriculture into the forest (Drouvot and Drouvot, 2011).

Overall, it is possible to conclude that oil palm plantations contribute to a reduction in diversity, but do not clearly modify the composition of the mayfly community. In comparison with other long-term crops, such as banana, the mayfly fauna was less affected in the present case, given that banana plantations may have a significant effect on both species richness and composition of aquatic insects (Kleine et al., 2011; Corbi et al., 2013). In sugarcane plantations, Corbi and Trivinho-Strixino (2008) found a lower diversity of taxa in comparison with areas of riparian vegetation, and a higher percentage of sensitive taxa in well-conserved habitats. In the case of short-cycle crops, such as rice (Mize et al., 2008), plantations may also modify the composition of aquatic macroinvertebrate assemblages.

This pattern is even clearer when the relatively small proportion of physical variables that differed significantly between plantation and forest habitats - only nine $(\sim 8 \%)$ of the 114 variables analyzed - is taken into account. The small number of variables affected by the implantation of oil palm plantations indicates that this type of crop may be less aggressive to the environment than other cultivars. This may be related to the large size of the oil palms, which may reach a height of $15 \mathrm{~m}$ (Campos and Carmélia, 2007), thus providing good cover for the soil against the effects of sun and rain, as well as a habitat structure similar to that of natural forest. In addition, the soil is not exposed on a regular basis, as in the case of short-cycle crops, such as rice, maize or soybean, given that the ground is covered by grass throughout the year, helping to retain humidity and nutrients.
Even though the cultivation of oil palms has less impact on the environment, it is important to note the need for the preservation of gallery forests. Under Brazilian legislation (the Brazilian Forest Code, federal law number $12651 / 12$ ), a 30-meter wide riparian zone of natural vegetation must be maintained permanently over any watercourse of less than $10 \mathrm{~m}$ in width. These areas of permanent preservation, together with the legal reserves of natural vegetation required for any rural property, may provide an important buffer that reduces runoff and the transfer of nutrients and other material into local bodies of water (Schäffer et al., 2011). Within the area of the present study, most of the streams have areas of permanent preservation, which almost certainly contribute to reduced impact of this land use.

Three $(43 \%)$ of the seven limnological variables were affected by the plantations, which indicates that these factors may be more affected by the cultivation of oil palms than the physical characteristics of the streams. The associations between Ephemeroptera taxa and limnological variables were expected, given the marked sensitivity of these insects to such factors (Shimano et al., 2013). A number of studies have reported the sensitivity of Ephemeroptera to contaminants, such as heavy metals, ammonia and other chemical compounds (Clements et al., 2002), and the potential of these insects for biomonitoring. Such contaminants have a major impact on local human populations, given that most residents of the study area depend on streams that cross oil palm plantations for drinking water and bathing. The water of these streams is contaminated with the pesticides used in the oil palm plantations, which provoke itching and boils (Glass, 2013). Clearly, it would be important to implement stricter controls on the quantity and types of herbicides, insecticides and fungicides used in this type of plantation.

As monitoring and regulation of the quality of stream water that flows through agricultural areas is often difficult or financially not viable, the biomonitoring of live organisms may represent an extremely useful option for the detection of variations in the physical-chemical attributes of the water, given that it avoids the need for daily or even weekly measurements, considering that the presence or absence of specific taxa may indicate long-term impacts on the environment. In the case of the Ephemeroptera, the genera most clearly indicated by the TITAN (the highest number of variables) were Ulmeritoides and Miroculis, with Ulmeritoides being invariably associated with the variable related to the plantation habitats, and Miroculis to those of the forest. However, no data are available on the biology of these genera that might provide insights into the factors that determine the differences in their sensitivity to habitat modifications. Ulmeritoides appears to have a preference for calmer waters, such as those of marshes associated with rithral habitats, in which the structure of their gills (which have a large number of filaments) may represent an adaptation for the efficient absorption of oxygen (Da-Silva et al., 2010). An indeterminate species of Ulmeritoides has also been found in river sectors with almost no current, which form a series of pools 
(Nolte et al., 1997). However, Domínguez et al. (2006) collected Ulmeritoides specimens from leaf and wood litter in a range of conditions, varying from still pools to running water. Miroculis can be found in both rithral and potamal habitats, and even in reservoirs (Da-Silva et al., 2010) occupying a wide range of substrates (Domínguez et al., 2006).

For the other genera that presented some association with specific variables (Campylocia and Campsurus), responses varied according to the type of variable analyzed. Campsurus was only affected by physical variables, which may be related to the behavior of the larvae of this genus, which live underground, digging U-shaped tunnels, preferentially in soft, clayey sediments, which represent a physical variable (Domínguez et al., 2006).

The results of the TITAN also indicated thresholds for each variable and associated genus. Based on these data, the impact of a change to a specific variable on the Ephemeroptera assemblages can easily be predicted. For example, when the temperature decreases to below $24.75{ }^{\circ} \mathrm{C}$, Miroculis tends to disappear (see change points and indications in Table 3). Based on the threshold presented for each variable, it is possible to predict the impacts and modifications of the assembly for each variable, facilitating the establishment of preventive measures to maintain the aquatic diversity of these habitats.

Overall, then, Ulmeritoides and Miroculis appear to be the principal candidates for the effective biomonitoring of areas with oil palm plantations. This is reinforced by the fact that these genera are easily identified by specific morphological traits. Both genera can be identified with the structure of the gills, which are composed of two lamellae. In Ulmeritoides, the gills are oval in shape, with a fringe around the whole of their edges, while in Miroculis, they are lanceolate, with hyaline lateral wings of varying shapes (Appendix Fig. A1).

While the implantation of oil palm plantations may be a viable strategy for the recuperation of degraded areas in the Amazon basin, it requires careful monitoring in order to ensure that forested areas are not encroached on, and in particular that areas of permanent preservation are maintained intact.

The results of the present study indicate that oil palm plantations may be less damaging to the region's biodiversity than other agricultural practices, in particular cattle ranching, which is the principal driver of deforestation in the Amazon basin (Rivero et al., 2009). It is important to remember, however, that the present study focused on aquatic invertebrates, and that more conclusive guidelines would require reliable data on terrestrial invertebrates, as well as aquatic and terrestrial vertebrates.

It is important to note that, while oil palm plantations may have a positive role to play in the recuperation of degraded and deforested areas, where this cultivar may be both economically and ecologically viable, the deforestation of pristine areas for the implantation of this activity cannot be recommended. Similarly, while the present study has shown that oil palm cultivation may be less damaging to the local aquatic fauna than other cultivars or cattle ranching, additional studies are clearly needed in order to confirm whether organic oil palm plantations would be an even more effective solution for the recuperation of abandoned and exposed soils in the Amazon basin.

Acknowledgements. We thank the participants of the Laboratório de Ecologia e Conservação of Universidade Federal do Pará for their assistance with the fieldwork, Erlane Cunha for the organization of the environmental data and Propesp for manuscript translation. The Conselho Nacional de Desenvolvimento Científico e Tecnológico (CNPq) provided LJ (process 303252/2013-8) with research fellowships. We also thank Agropalma and Conservação Internacional for supporting fieldwork.

\section{References}

Agropalma, 2014. Sobre a Agropalma, Accessed online June 2014, http://www.agropalma.com.br

Albuquerque M.F., Souza E.B., Oliveira M.C.F. and Souza-Jr J.A., 2010. Precipitação nas mesorregiões do Estado do Pará: Climatologia, variabilidade e tendências nas últimas décadas (1978-2008). Rev. Bras. Climatol., 6, 151-168.

Baker M.E. and King R.S., 2010. A new method for detecting and interpreting biodiversity and ecological community thresholds. Method. Ecol. Evol., 1, 25-37.

Barbour M.T., Gerritsen J., Griffith G.E., Frydenborg R., McCarron E., White J.S. and Bastian M.L., 1996. A framework for biological criteria for Florida streams using benthic macroinvertebrates. J. North Am. Benthol. Soc., 15, 185-211.

Bottová K., Derka T. and Svitok M., 2012. Life history and secondary production of mayflies (Ephemeroptera) indicate disturbance in two small Carpathian streams. Int. Rev. Hydrobiol., 97, 100-116.

Buss D.F. and Salles F.F., 2007. Using Baetidae species as biological indicators of environmental degradation in a Brazilian river basin. Environ. Monit. Assess., 130, 365-372.

Butler R.A. and Laurance W.F., 2009. Is oil palm the next emerging threat to the Amazon? Trop. Conserv. Sci., 2, 1-10.

Campos A.A. and Carmélia E.C., 2007. Viabilidade de extração de óleo de dendê no estado do Pará, Ministério do Desenvolvimento Agrário, Viçosa.

Clarke K.R. and Warwick R.M., 1994. Similarity-based testing for community pattern: the two-way layout with no replication. Mar. Biol., 118, 167-176.

Clements W.H., Carlisle D.M., Courtney L.A. and Harrahy E.A., 2002. Integrating observational and experimental approaches to demonstrate causation in stream biomonitoring studies. Environ. Toxicol. Chem., 21, 1138-1146.

Coddington J.A., Griswold C.E., Davila D.S., Penaranda E. and Larcher S.F., 1991. Designing and testing sampling protocols to estimate biodiversity in tropical ecosystems. In: Dudley E.C. (ed.), The unity of evolutionary biology: Proc. of the Fourth Int. Congress of Systematic an Evolutionary Biology, Dioscorides Press, Portland OR, Vol. 2, 44-60.

Colwell R.K., 2005. Estimates: Statistical estimation of species richness and shared species from samples. Version 7.5. User's 
Guide and application published at: http://purl.oclc.org/ estimates.

Colwell R.K. and Coddington J.A., 1994. Estimating terrestrial biodiversity through extrapolation. Phil. Trans. R. Soc. B, $345,101-118$.

Corbi J.J. and Trivinho-Strixino S., 2008. Relationship between sugar cane cultivation and stream macroinvertebrate communities. Braz. Arch. Biol. Technol., 51, 769-779.

Corbi J.J., Kleine P. and Trivinho-Strixino S., 2013. Are aquatic insect species sensitive to banana plant cultivation? Ecol. Indic., 25, 156-161.

Corley R.H.V., 2009. How much palm oil do we need? Environ. Sci. Policy, 12, 134-139.

Couceiro S.R.M., Hamada N., Forsberg B.R., Pimentel T.P. and Luz S.L.B., 2012. A macroinvertebrate multimetric index to evaluate the biological condition of streams in the Central Amazon region of Brazil. Ecol. Indic., 18, 118-125.

Cunha E.J., Montag L.F.A. and Juen L., 2015. Oil palm crops effects on environmental integrity of Amazonian streams and Hetereopteran (Hemiptera) species diversity. Ecol. Indic., 52, 422-429.

Da-Silva E.R., Nessimian J.L. and Coelho L.B.N., 2010. Leptophlebiidae ocorrentes no Estado do Rio de Janeiro, Brasil: hábitats, meso-hábitats e hábitos das ninfas (Insecta: Ephemeroptera). Biota Neotrop., 10, 87-94.

Danielsen F., Beukema H., Burgess N.D., Parish F., Brühl C.A., Donald P.F., Murdiyarso D., Phalan B., Reijnders L., Struebig M. and Fitzherbert E.B., 2008. Biofuel plantations on forested lands: double jeopardy for biodiveristy and climate. Conserv. Biol., 23, 348-358.

Domínguez E., Molineri C., Pescador M.L., Hubbard M.D. and Nieto C., 2006. Ephemeroptera of South America, Pensoft, Moscow, $646 \mathrm{p}$.

Drouvot C.M. and Drouvot H., 2011. O Programa de Produção Sustentável do Dendê na Amazônia: a mobilização dos grupos de interesse no reflorestamento das áreas degradadas. $6^{\circ}$ Congresso do Instituto Franco-Brasileiro de Administração de Empresas, 1, 1-16.

Dufrêne M. and Legendre P., 1997. Species assemblages and indicator species: the need for a flexible asymmetrical approach. Ecol. Monogr., 67, 345-366.

Eftenoiu C.C., Petrovici M. and Pârvulescu L., 2011. Assessment on the Ephemeroptera distribution (Insecta) in relation with aquatic parameters in different rivers from Aninei Mountains (SW Romania). AACL Bioflux, 4, 27-39.

Fitzherbert E.B., Struebig M.J., Morel A., Danielsen F., Brühl C.A., Donald P.F. and Phalan B., 2008. How will oil palm expansion affect biodiversity? Trends Ecol. Evol., 23, $538-545$.

Foley J.A., DeFries R., Asner G.P., Barford C., Bonan G., Carpenter S.R., Chapin F.S., Coe M.T., Daily G.C., Gibbs H.K., Helkowski J.H., Holloway T., Howard E.A., Kucharik C.J., Monfreda C., Patz J.A., Prentice C., Ramankutty N. and Snyder P.K., 2005. Global consequences of land use. Science, 309, 570-574.

Glass V., 2013. Expansão do dendê na Amazônia brasileira: Elementos para uma análise dos impactos sobre a agricultura familiar no nordeste do Pará, Repórter Brasil, São Paulo, $15 \mathrm{p}$.

Hepp L.U. and Santos S., 2009. Benthic communities of streams related to different land uses in a hydrographic basin in southern Brazil. Environ. Monit. Assess., 157, 305-318.
King R.S. and Richardson C.J., 2003. Integrating bioassessment and ecological risk assessment: an approach to developing numerical water-quality criteria. Environ. Manage., 31, 795-809.

King R.S., Baker M.E., Kazyak P.F. and Weller D.E., 2011. How novel is too novel? Stream community thresholds at exceptionally low levels of catchment urbanization. Ecol. Appl., 21, 1659-1678.

Kleine P., Trivinho-Strixino S. and Corbi J.J., 2011. Relationship between banana plant cultivation and stream macroinvertebrate communities. Acta Limnol. Bras., 23, 344-352.

Koh L.P. and Wilcove D.S., 2008. Is oil palm agriculture really destroying tropical biodiversity? Conserv. Lett., 1, 60-64.

Kongsager R. and Reenberg A., 2012. Contemporary Land-use Transitions: The Global Oil Palm Expansion, GLP-IPO, Copenhagen, $44 \mathrm{p}$.

Krebs C.J., 1999. Ecological Methodology, Addison-Wesley Longman, Inc., Menlo Park, CA, 620 p.

Legendre P. and Legendre L., 2012. Numerical Ecology, Elsevier, Amsterdam, 990 p.

Lucey J.M., Tawatao N., Senior M.J.M., Khen C.V., Benedick S., Hamer K.C., Woodcock P., Newton R.J., Bottrell S.H. and Hill J.K., 2014. Tropical forest fragments contribute to species richness in adjacent oil palm plantations. Biol. Conserv., 169, 268-276.

Menetrey N., Oertli B., Sartori M., Wagner A. and Lachavanne J.B., 2008. Eutrophication: are mayflies (Ephemeroptera) good bioindicators for ponds? Hydrobiologia, 597, 125-135.

Mercer E.V., Mercer T.G. and Sayok A.K., 2013. Effects of forest conversions to oil palm plantations on freshwater macroinvertebrates: a case study from Sarawak, Malaysia. J. Land Use Sci., 1-18, doi: 10.1080/1747423X. 2013.786149.

Mize S.V., Porter S.D. and Demcheck D.K., 2008. Influence of fipronil compounds and rice-cultivation land-use intensity on macroinvertebrate communities in streams of southwestern Louisiana, USA. Environ. Pollut., 152, 491-503.

Monteiro-Júnior C.S., Couceiro S.R.M., Hamada N. and Juen L., 2013. Effect of vegetation removal for road building on richness and composition of Odonata communities in Amazonia. Brazil. Int. J. Odonatol., 16, 135-144.

Nessimian J.L., Venticinque E.M., Zuanon J., De Marco P., Gordo M., Fidelis L., Batista J.D. and Juen L., 2008. Land use, habitat integrity, and aquatic insect assemblages in Central Amazonian streams. Hydrobiologia, 614, 117-131.

Nolte U., Oliveira M.J. and Sturs E., 1997. Seasonal, dischargedriven patterns of mayfly assemblages in an intermittent Neotropical stream. Freshw. Biol., 37, 333-343.

Peck D.V., Herlihy A.T., Hill B.H., Hughes R.M., Kaufmann P.R., Klemm D.J., Lazorchak J.M., McCormick F.H., Peterson S.A., Ringold P.L., Magee T. and Cappaert M., 2006. Environmental Monitoring and Assessment ProgramSurface Waters Westerns Pilot Study: Field Operations Manual for Wadeable Streams EPA/620/R-06/003. U.S. Environmental Protection Agency, Office of Research and Development, Washington, DC.

R Development Core Team, 2014. R: A Language and Environment for Statistical Computing, R Foundation for Statistical Computing, Vienna, Austria. Ref Type: Computer Program. 
Ramalho-Filho A. and Mota P.E.F., 2010. Contexto e objetivos do Zoneamento Agroecologico para cultura da palma de óleo nas áreas desmatadas da Amazônia Legal. In: RamalhoFilho A. (ed.), Zoneamento agroecológico, produção e manejo da cultura de palma de óleo na Amazônia, Embrapa Solos, Rio de Janeiro, 19-22.

Rivero S., Almeida O., Ávla S. and Oliveira W., 2009. Pecuária e desmatamento: uma análise das princiapais causas diretas do desmatamento na Amazônia. Nova Econ., 19, 41-66.

Rocha M.G. and Castro A.M.G., 2012. Fatores limitantes à expansão dos sistemas produtivos de palma na Amazônia Departamento Trasnferência de Tecnologia, Brasília.

Schäffer W.B., Rosa M.R., Aquino L.C.S. and Medeiros J.D., 2011. Áreas de Preservação Permanente e Unidades de Conservação and Áreas de Risco. O que uma coisa tem a ver com a outra? Ministério do Meio Ambiente, Brasília, $193 \mathrm{p}$.

Sheil D., Casson A., Meijaard E., Van Nordwijk M., Gaskell J., Sunderland-Groves J., Wertz K. and Kanninen M., 2009.
The impacts and opportunities of oil palm in Southeast Asia: What do we know and what do we need to know? Occasional paper $n^{\circ}$ 51. CIFOR, Bogor, Indonesia.

Shimano Y., Cabette H.S.R., Salles F.F. and Juen L., 2010. Composição e distribuição da fauna de Ephemeroptera (Insecta) em área de transição Cerrado-Amazônia, Brasil. Iheringia, 100, 301-308.

Shimano Y., Juen L., Salles F.F., Nogueira D.S. and Cabette H.S.R., 2013. Environmental and spatial processes determining Ephemeroptera (Insecta) structures in tropical streams. Ann. Limnol. - Int. J. Lim., 49, 31-41.

Silva D.P., De Marco P. and Resende D.C., 2010. Adult odonate abundance and community assemblage measures as indicators of stream ecological integrity: a case study. Ecol. Indic., 10, 744-752.

Souza H.M.L., Cabette H.S.R. and Juen L., 2011. Baetidae (Insecta, Ephemeroptera) em córregos do cerrado matogrossense sob diferentes níveis de preservação ambiental. Iheringia Ser. Zool., 101, 181-190. 


\section{Appendices}

Table A1. Results of the $\mathrm{t}$ tests for the limnological and physical variables (only those which presented significant differences) measured in the plantation and forest streams.

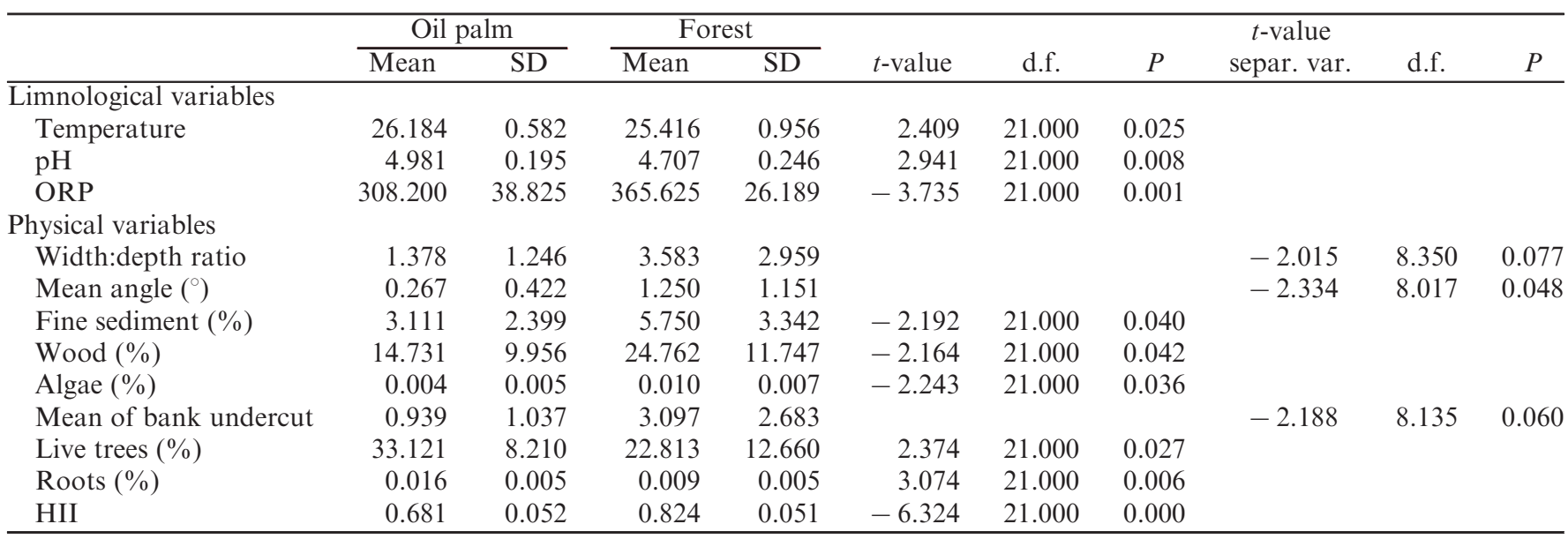

df, Degrees of Freedom; $t$-value separ. var., $t$ test with separated variance.
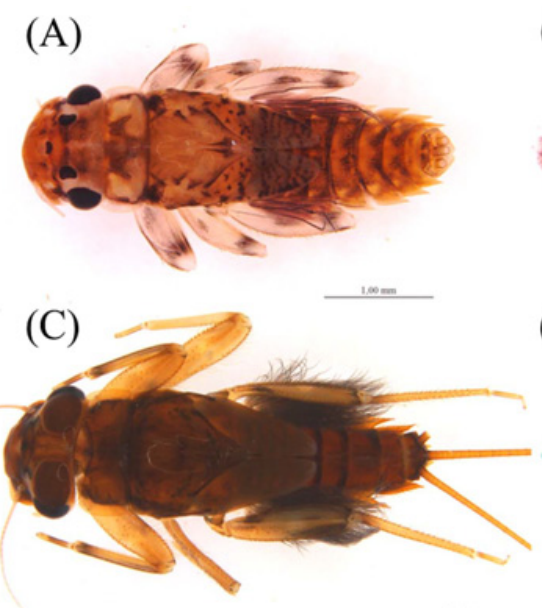

(B)

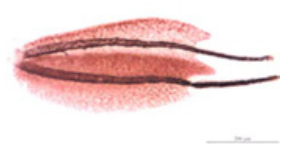

(D)

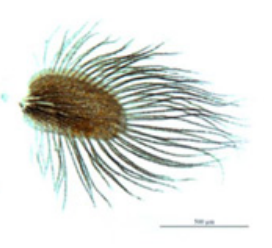

Fig. A1. Ephemeroptera genera associated with Forest (A, B) and oil palm cultivation (C, D). (A) Miroculis and (B) detail of the gill; (C) Ulmeritoides and (D) detail of the gill. 